\title{
ENTREVISTA COM OLGA SAVARY
}

\author{
Rosa Maria Severino Ueno 1 \\ -Universidade de Brasília, Brasília, Distrito Federal, Brasil
}

Pioneira da poesia erótica no Brasil, a poeta (como prefere ser chamada), escritora, jornalista e tradutora Olga Savary há mais de quatro décadas vem trabalhando em traduções de grandes obras literárias, ademais de contar com inúmeros prêmios e reconhecimentos por sua obra própria. É a maior tradutora de Pablo Neruda no Brasil, além de ter traduzido importantes autores da literatura hispano-americana, como Octavio Paz, Carlos Fuentes, Julio Cortázar, Mario Vargas Llosa e Laura Esquivel. Em 1980 recebeu da Academia Brasileira de Letras o Prêmio Odorico Mendes de Tradução, por Conversa na Catedral, e em 1994 o Prêmio Jabuti de Tradução, por Como água para chocolate. Também traduziu indiretamente a três grandes mestres nipônicos do haicai: Bashô, Buson e Issa. Em entrevista, a autora, do alto dos seus 84 anos, nos conta, em seu apartamento do Rio de Janeiro, sobre sua trajetória como tradutora com histórias irônicas e espirituosas.

Cadernos de Tradução (CT): Você viveu rodeada de livros desde a infância?

Olga Savary (OS): Sempre! Comecei a me interessar por livros desde criança, ainda era bem pequena quando fui apresentada ao haicai. Eu ia até a biblioteca do meu tio, pegava um livro de poesia e perguntava "como se chama esta poesia tão curtinha de três versos?", e ele me dizia "ah, isso é poesia de origem japonesa!", 
e foi paixão à primeira vista! No início eu comecei a ler haicai em francês e inglês, com a ajuda de meu tio, e desde então passei a devorar livros de haicai e acabei me tornando a primeira mulher no Brasil a escrever esta forma poética.

CT: Você é considerada uma mulher vanguardista, esteve no Pasquim desde o seu início. Como você avalia esse período da sua vida?

OS: Eu participei da fundação do Pasquim ${ }^{1}$ e me mantive por lá de 1969 até 1982. Iniciei meu trabalho como colaboradora, entrevistadora e tradutora. Minha coluna "As Dicas" continha opiniões sobre música, livros e artes em geral. Fui eu quem publicou pela primeira vez uma resenha sobre a Elis Regina, que na época estava dando seus primeiros passos na carreira, depois ela virou aquela celebridade.

CT: Hoje, aos 84 anos, você é considerada a maior poeta viva do Brasil, além de ter realizado um importante trabalho como tradutora. Como você entrou no universo da tradução?

OS: Traduzir foi quase que automático desde que comecei a escrever. Comecei de forma natural, traduzindo haicais, porque eu adoro desafios, depois comecei a traduzir profissionalmente. É um trabalho árduo, porque sou muito perfeccionista em tudo o que eu faço, então sou capaz de ficar meses em cima de uma tradução. Desde os anos 1960, traduzi várias obras poéticas, a maioria de Pablo Neruda, além de ensaios, novelas e dramas.

\footnotetext{
${ }^{1}$ Sobre a fundação do Pasquim, em entrevista concedida à revista Marie Claire, Olga declarou que: "os louros ficaram com os homens da redação, mas eu fui uma das fundadoras do Pasquim". Cf.: http://revistamarieclaire.globo.com/Revista/ Common/0,,ERT162428-17737,00.html.
} 
CT: Você é filha de um imigrante russo e, no entanto, em seu trabalho não consta nenhuma tradução da língua russa. Você não teve interesse em aprender o idioma do seu pai?

$O S$ : Eu quis aprender, mas meu pai não quis me ensinar. Ele queria que eu aprendesse alemão, então fui estudar em uma escola alemã. Hoje eu me arrependo porque o alemão é uma língua interessante e curiosa, mas na época, ainda garota, eu não queria aprendê-lo, talvez pelo trauma da guerra. Eu tinha horror à supremacia alemã, sobretudo a Hitler. Então quando fui para um colégio brasileiro, mergulhei nos estudos de outras línguas ocidentais: inglês, francês e espanhol.

CT: A maior parte das suas traduções veio da língua espanhola, embora você também tenha traduzido do inglês e francês. Você tinha alguma preferência especial pelo espanhol?

OS: A maioria das minhas traduções de fato foi feita do espanhol, mas não tinha preferência por esta língua, foi uma casualidade. As traduções do espanhol naquela época eram as mais solicitadas entre os meus parceiros profissionais. Mas eu também traduzi muitos trabalhos do inglês e do francês. Eu traduzi, por exemplo, as obras de Oscar Wilde do inglês. Apanhei como uma louca, porque foi uma tradução muito difícil, aliás, foi a tradução mais difícil que fiz na minha vida, porque eu fiz em uma máquina Olivetti, ao invés de escrever à mão como eu estava habituada. Foi um trabalho penoso de um ano e meio e, quando chegou ao fim, o que foi cobrado já não valia todo o esforço dispendido.

CT: Você chegou a recusar alguma obra do período do boom literário hispano-americano? 
OS: Não. Eu tenho quase certeza que não recusei nenhum trabalho nesta época. Porque, felizmente, não vinham todas as traduções ao mesmo tempo. Vinha um trabalho, passavam-se meses, vinha outro. E quando chegavam dois trabalhos muito bons ao mesmo tempo eu dizia "olha, eu já estou fazendo tal tradução, assim, você espera?" E geralmente todos os colaboradores aceitavam. Porque eles sabiam que eu era perfeccionista. Alguns até diziam "você nem precisa de revisão, quando você entrega a tradução, ela já está pronta para enviar à gráfica". No geral, o trabalho de um tradutor tinha que passar por uma revisão, ou duas, três... Não era o meu caso!

CT: Sua primeira tradução de Pablo Neruda foi aos 17 anos, lembra-se qual foi a obra?

OS: Lembro sim, foi do livro Vinte poemas de amor e uma canção desesperada, que até hoje não foi publicada, e sabe por quê? Porque já havia uma tradução da mesma obra. Então eles não queriam reiterar o mesmo trabalho, o que eu acho uma bobagem, porque se você faz uma tradução, outra pessoa faz e eu faço, torna-se interessante, você tem mais de uma escolha, pode comparar uma tradução com a outra, mas as editoras não pensavam desta forma. Quando se é jovem cometemos alguns enganos, como, por exemplo, achar que eu era a primeira a ter a ideia de traduzir esse livro.

\section{CT: Você conheceu o escritor Pablo Neruda pessoalmente?}

OS: Nunca conheci o Neruda. Uma vez eu cruzei com ele em uma rua de Ipanema, ele me deu um sorriso e me olhou como quem tivesse me reconhecido, do tipo "ah, essa aí é aquela que saiu no jornal”. Mas eu era tímida, não falei com ele, nem sorri. Eu fiquei séria. Ele sorriu pra mim. Eu não correspondi. Atravessei a rua, a gente se cruzou e foi só. Hoje me arrependo, gostaria de ter dito a ele "olá, eu sou Olga, sua principal tradutora neste país”. 
CT: Você alguma vez chegou a consultar diretamente um escritor em algum momento complicado da tradução?

OS: Não, não, novamente caí na armadilha da timidez de ficar chateando o autor, sabe? Eu queria resolver sozinha, eu amava o desafio e dizia a mim mesma: "eu vou conseguir, não vou procurar o autor". O que é uma bobagem, porque perguntando para o autor você ganha um tempo precioso. Lembro-me de uma vez que apanhei horrores com um nome de um arco arquitetônico, em uma tradução de Neruda, levei meses para achar uma resposta, para você ter uma ideia eu bati na porta do Oscar Niemeyer e nem ele se lembrava, isso me deixou traumatizada na época. Para falar a verdade uma única vez eu tive um contato, foi com o Octavio Paz, mas a tradução já estava feita.

\section{CT: E como foi esse encontro com o Octavio Paz?}

OS: Eu o conheci no Consulado do México, no Rio de Janeiro, durante um jantar que o Cônsul ofereceu para ele e para sua esposa Marie-José. Em um determinado momento eu disse a ele "você sabe que eu traduzi oito livros seus?", aí ele caiu das nuvens e ficou encantado, e me disse: "poxa, você traduziu oito livros meus?". E a partir desse momento tivemos uma noite agradabilíssima. Ele era um orientalista, amava a Índia!

\section{CT: Você já teve algum trabalho de tradução plagiado?}

OS: Ao longo da minha carreira tenho pelo menos uns dez casos de má fé de outras pessoas com o meu trabalho. Certa vez, uma de minhas traduções foi "roubada". Por conta própria fiz a tradução de uma obra significativa e entreguei a um editor ${ }^{2}$ muito conhecido,

2 A pedido da entrevistada, os nomes da obra e do editor foram omitidos na transcrição desta entrevista.

Cad. Trad., Florianópolis, v. 39, no 2, p. 305-315, mai-ago, 2019. 
que inclusive era um amigo. Algum tempo depois, a obra apareceu publicada com uma ou outra alteração de palavras, e sem o meu nome. Em um natal eu me encontrei com esse editor, que era muito próximo a mim, e então perguntei: "que história é essa de você pegar minha tradução e não me dar os créditos?", ele respondeu "ah, não vamos falar nisso agora". Ele fugiu do assunto e acabou ficando por isso mesmo. Acho que isso foi uma grande picaretagem da parte dele. Também me lembro de um professor de uma importante universidade, poeta, que durante anos ameaçou usar o título Repertório Selvagem, nome da minha obra de poesia reunida, em uma obra que ele iria escrever. Ele não fez isso, mas ameaçou por mais de 20 anos. Deste episódio aprendi a nunca mais anunciar o título do meu próximo livro.

CT: Olga, durante a tradução da obra Conversa na Catedral, do Vargas Llosa, lançada em 1977 pela editora Francisco Alves, houve rumores sobre alguns desentendimentos com o título deste livro, pode nos dizer o que aconteceu?

OS: Sim houve um desentendimento, briguei, "entre aspas", com a Editora, porque eu dizia que o título deveria ser "Conversa no Catedral”. E argumentava: "La Catedral é um bar, gente, não é uma catedral e nem uma igreja, é o nome de um bar, uma espécie de botequim de quinta categoria". Mas a editora não aceitava, eu ainda dizia, "mas ficará diferente". E eles: "não, não pode. Tem que ser na Catedral”. Daí colocaram "na Catedral”. E ficou como se fosse uma igreja. Paciência, ficou assim. Anos depois me disseram que Vargas Llosa, em uma entrevista concedida à TV Globo, parabenizou o meu trabalho no Brasil, como sua tradutora. Ele tinha mania de escrever sem botar ponto e vírgula, e ficava irritado com a revisão que faziam em seus livros, com exceção das minhas traduções, porque respeitei cada detalhe da sua obra. 
CT: Mario Vargas Llosa disse que se tivesse que salvar apenas uma de suas obras do fogo, salvaria Conversa na Catedral. Considerando o vanguardismo e o estilo da obra, na época da tradução você chegou a imaginar que algum dia ele seria Prêmio Nobel de Literatura?

OS: Não, não tinha ideia. Mas durante a tradução, cada vez que eu chegava ao final do livro, em cada revisão eu chorava. Havia um personagem horroroso, o Cayo $\mathrm{Merda}^{3}$, eu o via de noite na minha casa, eu ouvia os seus passos. Eu tinha pânico desse personagem. E cada vez que eu chegava ao último capítulo eu chorava loucamente. Isso nunca tinha acontecido antes, jamais um trabalho me trouxe tanta emoção.

CT: Ao longo da sua carreira você ganhou muitos prêmios, não só como autora, mas também como tradutora. Qual o significado de ambos para você?

$O S$ : Eu ganhei mais prêmios como autora, de fato, mas ganhei muitos outros como tradutora. Recebi alguns como o prêmio Odorico Mendes, na década de 1980, com a obra Conversa na Catedral, do Vargas Llosa. Lembro-me também, com carinho, do Prêmio da União Brasileira de Escritores pela Tradução por Vislumbres da Índia, do Octavio Paz. Mas a verdade é que naquela época eu não ligava muito para isso. Hoje todos eles são importantes para mim!

CT: Considerando que, tanto a escrita quanto a tradução de uma obra são processos criativos e autorais, em que medida o seu lado autora contribuiu para o lado tradutora e vice-versa?

${ }^{3}$ Cayo Bermúdez, apelidado de Cayo Merda, é o principal mandante da repressão política da ditatura do general Odría.

Cad. Trad., Florianópolis, v. 39, no 2, p. 305-315, mai-ago, 2019. 
OS: Ótima pergunta, porque eu acho o seguinte, se você não é escritor, se você não é poeta, principalmente poeta, você não tem condição de traduzir poesia. Não tem como. A tradução de um livro de poesia por um camarada que é ficcionista, mesmo quando ficcionista, não vai funcionar, não vai prestar, como dizem na minha terra. Não presta, porque você não vai ter aquele jogo de cintura necessário para sentir cada palavra e depois traduzi-la. Na prosa é diferente, mas para traduzir poesia você tem que ser poeta, senão não evolui.

$\mathrm{CT}$ : E de todos os autores que você trabalhou, qual deles foi o mais prazeroso de se traduzir?

OS: Olha, neste momento tenho a impressão que foram os livros do Octavio Paz, porque ele é um ótimo poeta. Ele é mais reverenciado como ensaísta, mas não se pode negar que Paz escreveu poemas deslumbrantes. Mas o livro que eu mais amei traduzir foi Terra Nostra, de Carlos Fuentes. Trabalhar com esta obra foi uma paixão alucinante, porque realmente é poesia pura. Gente, um livro de mil e tantas páginas, com aquele teor poético, é uma loucura. Até hoje eu me pergunto: "como é que pode aquilo ter sido escrito?".

CT: Você chegou a traduzir alguma coisa do Jorge Luis Borges?

OS: Sim, alguns haicais, publicados somente em jornais. Não cheguei a traduzir um livro completo do Borges, mas eu o amava. Recordo-me que na época eu disse "eu não acredito que Borges escreveu haicais!". Eu acho que quando o poema é muito longo, o poeta se perde um pouco, se não for um grande poeta. Eliot, não. Eliot tem poemas imensos... Aliás, ele é o meu poeta preferido.

CT: De cabeceira, também?

Cad. Trad., Florianópolis, v. 39, no 2, p. 305-315, mai-ago, 2019. 
OS: Sim ele é meu poeta de cabeceira, meu poeta do coração. Poeta brasileiro para mim é Carlos Drummond de Andrade, mas no geral, de todos, Eliot para mim é o melhor, o que eu mais amo. Ele pode fazer poemas de muitas páginas, de trinta páginas, aqueles quartetos... e tudo me parece belo e perfeito.

CT: Você se lembra de algum desafio tradutório sedutor, em que tenha conseguido recriar de uma forma diferente?

OS: Sei que houve alguns, mas no momento não me recordo de nenhum; mas me lembro de uma frase do Baudelaire traduzida pelo genial Guilherme de Almeida, que originalmente dizia "perdeu a primavera seu gosto e sua cor". Guilherme traduziu assim "perdeu a primavera seu gosto de cor”. Eu acho fantástico. Quer dizer, é uma pequena transformação que acrescentou. Um primor. Eu sempre cito esta história porque é um belo exemplo de uma recriação com ganho. Para mim o tradutor nunca deixará de ser autor, mas como tradutores temos que respeitar o autor. Claro que você pode tomar algumas liberdades, como a que eu citei há pouco.

CT: Como você analisa a relação do tradutor, ou do autor, com o mercado editorial na atualidade?

OS: Com relação ao mercado editorial, tem certas questões que eu acho um absurdo, como o fato de o tradutor ganhar apenas na primeira edição de um livro, quer dizer, a editora faz quarenta edições e o tradutor só ganha na primeira tiragem? Isso já me aconteceu. $\mathrm{Eu}$ acho vergonhoso, mas o mercado editorial faz isso.

CT: Que recomendações você daria a um tradutor que está começando a se dedicar à tradução literária? Que qualidades essenciais essa pessoa deve ter? 
OS: Ser fiel ao trabalho do autor e ter o máximo de cuidado. O tradutor não pode chegar e dizer: "ah, eu vou fazer o que eu quero", eu acho isso errado. E acima de tudo, ter paixão, aliás, tudo o que você fizer na vida só vale se for com paixão, porque sem isso você não chega a lugar nenhum.

CT: Olga, você recebeu diversos prêmios como autora e como tradutora. Você se considera uma pessoa realizada?

OS: Não, porque eu acho que quando você está realizada, você morre. Vai morrer logo, pronto! E eu, mesmo aos 84 anos, ainda quero mais, e mais. Nunca estou satisfeita, e é assim que eu acho que tem que ser a vida. Se você pensar "ah, eu já fiz tudo o que eu tinha para fazer", a vida perde o sentido. Eu nunca tirei férias na minha vida. Férias para mim é quando eu vou a um congresso, e mesmo assim trabalho um pouquinho. Mas eu tenho mil projetos, e sei que não viverei o suficiente para realizar tudo o que eu gostaria.

\section{Referências}

Bashô. Hai-Kais de Bashô. Tradução de Olga Savary. São Paulo: Hucitec, 1989.

Vargas Llosa, Mario. Conversa na catedral. Tradução de Olga Savary. São Paulo: Círculo do Livro, 1977.

Esquivel, Laura. Como água para chocolate. Tradução de Olga Savary. São Paulo: Martins Fontes, 1993.

Fuentes, Carlos. Aura. Tradução de Olga Savary. Porto Alegre: L\&PM, 1981.

Cad. Trad., Florianópolis, v. 39, no 2, p. 305-315, mai-ago, 2019. 
Savary, Olga. Espelho provisório. Rio de Janeiro: José Olympio, 1979.

Savary, Olga. Sumidouro. São Paulo: Massao Ohno / João Farkas Editores, 1977.

Savary, Olga. Alta onda. Salvador/São Paulo: Macunaíma / Massao Ohno, 1979.

Savary, Olga. Magma. São Paulo: Massao Ohno / Roswitha Kempf, 1982.

Savary, Olga. Hai-Kais. São Paulo: Roswitha Kempf, 1976.

Recebido em: 13/12/2018

Aceito em: 19/03/2019

Publicado em maio de 2019

Rosa Maria Severino Ueno. Email: rosita.ueno@gmail.com. ORCID: http:// orcid.org/0000-0002-6194-5978

Cad. Trad., Florianópolis, v. 39, nº 2, p. 305-315, mai-ago, 2019. 